\title{
Fluxes of haemolymph ammonia and free amino acids in Mytilus edulis exposed to ammonia
}

\author{
Saloua Sadok ${ }^{1, *}$, Roger Uglow ${ }^{1}$, Stephen J. Haswell ${ }^{2}$ \\ ${ }^{1}$ University of Hull, Applied Biology, Hull HU6 7RX, United Kingdom \\ ${ }^{2}$ University of Hull, School of Chemistry, Hull HU6 7RX, United Kingdom
}

\begin{abstract}
Survival, weight-specific ammonia fluxes, blood ammonia levels and pH values were measured in individual mussels Mytilus edulis ( $\mathrm{L}$.) ( $\mathrm{n}=6$ in each group) sampled after various acute exposures (max. $2 \mathrm{~h}$ ) in normal or ammonia-enriched seawater Ammonia influxes occurred when external ammonia was $\geq 100 \mu \mathrm{mol} \mathrm{l}^{-1}$ when, within $5 \mathrm{~min}$, mean blood ammonia levels increased significantly by an amount directly proportional to the medium ammonia concentration. Blood pH showed an initial alkalosis followed by a slow acidosis. Blood ninhydrin-positive substance (NPS) levels showed a less rapid medium- $\mathrm{NH}_{4}$ concentration-dependent elevation and only the $100 \mathrm{mmol} \mathrm{l}^{-1}$-treated mussels showed a significant increase in blood NPS after 5 min exposure. Within the $2 \mathrm{~h}$ test period, no mortalities occurred in any group, though $50 \%$ of the $100 \mathrm{mmol}^{-1}$-treated group subsequently died after $6 \mathrm{~h}$ exposure. Apart from those in the most concentrated test medium, all mussels were seen to use apparently normal pumping behaviour, and it was concluded that $M$. edulis is an ammonia-tolerant species, capable of tolerating very high blood ammonia levels for extended periods of time. The toxic effect may be related more to the rate at which ammonia influx occurs, with the attendant level of disruption to the regulation of blood NPS levels, rather than to the actual blood ammonia concentration attained.
\end{abstract}

KEY WORDS: Ambient ammonia $\cdot$ Haemolymph ammonia $\cdot$ Haemolymph NPS $\cdot$ Mytilus edulis

\section{INTRODUCTION}

In several countries, nutrient-laden discharges from aquaculture, agriculture, forestry or sewage have resulted in serious eutrophication-induced oxygen depletion of the water and a high ammonia release from the sediment (Schaubs \& Gieskes 1991), both of which have adverse affects on shallow water benthic faunal species (Kristensen 1984, Brockmann et al. 1988, Parker 1988, Costello et al. 1993, Hatcher et al. 1994).

Attempts to 'clean' effluents chemically were shown to be unreliable (Ryther \& Dunstan 1971) and later attempts have been oriented towards finding effective biofilters as less expensive methods of water treatment. Seaweed and bivalves have been used in conjunction with salmon farms (Taylor et al. 1992j and shrimp farms (Enander \& Hasselstron 1994). Taylor et al. (1992) calculated that 68 to $86 \%$ of nitrogen con-

\footnotetext{
•E-mail: s.sadok@appbiol.hull.ac.uk
}

sumed by salmon is excreted and, as ammonia $\left(\mathrm{NH}_{4}\right.$ $\mathrm{N})$ is the principal nitrogenous excretory product of fish (Campell 1991), salmon farm effluents are $\mathrm{NH}_{4}-\mathrm{N}$ rich. However, both Taylor et al. (1992) and Enander \& Hasselstron (1994) attributed the $\mathrm{NH}_{4}-\mathrm{N}$ filtration. in their studies to its assimilation by phytoplankton or seaweed and no evaluation was made of possible $\mathrm{NH}_{4}$ $\mathrm{N}$ effects on Mytilus physiology.

Several studies have been made of the release and uptake of materials in association with mussel beds (Boucher \& Redoni 1988, Dame \& Dankers 1988, Prins \& Smaal 1992). Dame \& Dankers (1988) attributed the fluctuation of the ammonia efflux $(2.07$ to $6.06 \mathrm{mmol}$ $\mathrm{NH}_{4}-\mathrm{N} \mathrm{m}^{-2} \mathrm{~h}^{-1}$ ) to the variability of microbenthic algal uptake and not to the mussels themselves.

Although amino acid uptake from the medium by Mytilus edulis has been described in several studies (Crowe 1981, Wright et al. 1982, Manahan et al. 1983, Madhyastha et al. 1991) and the mechanism of amino acids transport across the body walls studied (Crowe 1981, Jørgensen 1983), few data are available on the 
mechanism of ammonia transport, its site of excretion, or its effect on this species, despite a number of similar studies made for other aquatic species.

After a period of debate as to the relative importance of amino acids and urea contribution to the total nitrogen excretion of Mytilus edulis (Bayne 1973b, 1976 , Bishop et al. 1983), it was shown by Manahan et al. (1983) and confirmed by Hawkins \& Bayne (1992) that ammonia is normally the only nitrogenous waste product excreted by this species.

Although they possess paired kidneys, the bulk of $\mathrm{NH}_{4}-\mathrm{N}$ clearance in Mytilus edulis occurs via the haemolymph at the gill epithelium, as with most ammonotelic aquatic animals (Rankin \& Davenport 1981, Eckert \& Randall 1983). In normal, low $\mathrm{NH}_{4}-\mathrm{N}$ media, downhill gradient of $\mathrm{pNH}_{3}$ and $\mathrm{NH}_{4}{ }^{+}$from the internal to the external medium occurs and results in $\mathrm{NH}_{4}-\mathrm{N}$ efflux. Experimental evidence has revealed at least 3 potential mechanisms for the extrusion of ammonia from the body. These include passive diffusion of $\mathrm{NH}_{3}$ down a partial pressure gradient (Kormanik \& Cameron 1981a), passive diffusion of $\mathrm{NH}_{4}{ }^{+}$ down an electrochemical gradient (Cameron 1986), and an apically located pump which exchanges intracellular $\mathrm{NH}_{4}{ }^{+}$for either external $\mathrm{Na}^{+}$or external $\mathrm{H}^{+}$, depending on the species (Mangum et al. 1978 , Cameron 1986, Wilson \& Taylor 1992). Methods used have included increasing ambient $\mathrm{NH}_{4}-\mathrm{N}$ levels to determine the effect on $\mathrm{NH}_{4}-\mathrm{N}$ efflux and using metabolic inhibitors, such as ouabain (Mangum et al. 1978) or amiloride (Wilson et al. 1994), which inhibit the active exchange of ions. Despite several attempts to quantify the relative importance of these mechanisms, $\mathrm{NH}_{4}-\mathrm{N}$ transport still remains a topic of debate and these studies with $M$. edulis were made as an attempt to resolve some of the issues involved.

The free amino acids (FAA) in Mytilus edulis, often measured as ninhydrin-positive substances (NPS) (Livingstone et al. 1979, Hawkins \& Hilbish 1992, Weber et al. 1992), and the nitrogen metabolism play a well-documented role in adjusting cellular osmolarity to changing environmental conditions (Bishop et al. 1983). Normally, $M$. edulis FAA concentrations are several-fold those of vertebrates and their haemolymph concentration varies from 0.2 to $5.0 \mathrm{mM}$ (Bishop et al. 1983) depending on diet, reproductive cycle and season. Following a period in hyperosmotic medium, $M$. edulis shows a decrease in $\mathrm{NH}_{4}-\mathrm{N}$ efflux and a net gain in the NPS pool (Livingstone et al. 1979, Hawkins \& Hilbish 1992) which could indicate ammonia-fixing mechanisms catalysed by enzymes such as alanine dehydrogenase (Livingstone et al. 1979) or glutamate dehydrogenase (Bishop et al. 1983). Nothing appears to be known of the effect of external $\mathrm{NH}_{4}-\mathrm{N}$ on $M$. edulis NPS levels but, in these studies, we conjecture that they may result in changes to the haemolymph NPS levels and of net $\mathrm{NH}_{4}-\mathrm{N}$ fluxes.

Ammonia is both a substrate and an end product of protein metabolism and may confer some other benefit, as Mytilus edulis has been found to grow in effluents with a permanent, relatively high $\mathrm{NH}_{4}-\mathrm{N}$ level (Enander \& Hasselstron 1994); Thomas et al. (1976) showed enhanced growth of the gastropod Biomphalaria glabrata in alkaline water with high ammonia concentration. Thus it appears that some species may be physiologically well adapted to cope with supranormal ambient $\mathrm{NH}_{4}-\mathrm{N}$ levels.

\section{MATERIALS AND METHODS}

Mytilus edulis (L.) were collected from the shore at Filey, Yorkshire, UK. In the laboratory, shells were scrubbed clean of all epibiota and stock mussels were kept for 2 wk in an aerated, circulating natural seawater $\left[10^{\circ} \mathrm{C}, \mathrm{S}\right.$ (salinity) $=32$ to $34 \mathrm{psu}$ ) system equipped with a biofilter and were fed with green algae Phaeodactylum tricornutum. For 1 wk prior to the experiments, the mussels were not fed. Two series of experiments were made.

Haemolymph sampling. The shell valves were prised apart slightly with a scalpel to allow water in the mantle cavity to drain. An indentation was then made at the dorsal edge of the valves, close to the heart, and haemolymph was drawn from the heart using a gastight syringe (Hamilton).

Expt 1: The first experiment comprised an investigation of the ability of mussels to take up ammonia from the medium. A series of test solutions $(0,20,100$, 200, 400 and $500 \mu \mathrm{mol} \mathrm{NH}_{4}-\mathrm{N} \mathrm{l}^{-1}$ and 1.6, 2.0 and $2.8 \mathrm{mmol} \mathrm{NH}_{4}-\mathrm{N}^{-1}$ ) were made from a 'mother' concentration of Analar grade ammonium chloride (Sigma) using natural, virtually ammonia-free seawater ( $\mathrm{S}=34 \mathrm{psu}$ ). Only mussels of shell length 4 to $5 \mathrm{~cm}$ were selected, and the shells of these were lightly brushed again to minimize the effect of adhering bacteria. Nine groups (pooling 20 mussels in each case) were transferred to containers, each containing $500 \mathrm{ml}$ of test solution. Controls comprised a series of containers, each containing $500 \mathrm{ml}$ of one of the test solutions only. To avoid the possible loss of volatile $\mathrm{NH}_{3}$ and the effects of bacterial action, experiment duration was kept to $2 \mathrm{~h}$ in all cases. After 1 and $2 \mathrm{~h}$ of incubation, water samples $(1.5 \mathrm{ml})$ were collected from each test container for total ammonia analysis using a flow injection/gas diffusion system (FIA) (Hunter \& Uglow 1993)

Following the collection of the $2 \mathrm{~h}$ exposure water sample, all mussels (except the $1.6 \mathrm{mM} \mathrm{NH}_{4}$ - $\mathrm{N}$-treated group) were left in the test solutions for $48 \mathrm{~h}$ in order to 
determine whether behavioural changes or mortality occurred. Six of the mussels exposed for $2 \mathrm{~h}$ to the $1.6 \mathrm{mM}$ $\mathrm{NH}_{4}-\mathrm{N}$ test solution were then reimmersed in normal seawater for a further $2 \mathrm{~h}$, during which water samples were collected after 1 and $2 \mathrm{~h}$ for ammonia analysis.

Expt 2: The second experiment comprised an investigation of the responses of individual Mytilus edulis to $\mathrm{NH}_{4}-\mathrm{N}$ exposure in the range 3.2 to $100 \mathrm{mM} \mathrm{NH}_{4}-\mathrm{N}$ (Table 1). The $\mathrm{pH}$ values of the test solutions were measured using a Jencon PHM2 pH meter and are included in Table 1.

Individual mussels were incubated in $100 \mathrm{ml}$ of $\mathrm{NH}_{4}$ $N$-free seawater from which water samples $(1.5 \mathrm{ml})$ were taken after 1 and $2 \mathrm{~h}$. Each mussel was then transferred to $100 \mathrm{ml}$ of one of the test solutions and water samples $(1.5 \mathrm{ml})$ were collected after 5, 15, 30, 45, 60 and $120 \mathrm{~min}$. At the time of each test water sample collection, a haemolymph sample was taken from 6 mussels from each test solution. Those mussels were then removed from the experiment. Haemolymph $\mathrm{pH}$ was measured immediately for mussels exposed to 3.2 and $6 \mathrm{mM} \mathrm{NH}_{4}-\mathrm{N}$. A measured quantity (ca $100 \mu$ l) of each blood sample was diluted with saline $(\mathrm{NaCl}$, $\left.9.0 \mathrm{~g} \mathrm{l}^{-1}\right)$ for measurement of ammonia $\left(\mathrm{NH}_{4}-\mathrm{N}\right)$ and NPS. These samples were frozen $\left(-20^{\circ} \mathrm{C}\right)$ immediately to inhibit enzyme action.

Three groups ( $\mathrm{n}=6$ each) of mussels were exposed to $3.2,6$ and $10 \mathrm{mM} \mathrm{NH}_{4}-\mathrm{N}$ for $2 \mathrm{~h}$ and were then reimmersed individually in ammonia-free seawater for a further $2 \mathrm{~h}$. Water samples were collected at 1 and $2 \mathrm{~h}$ of reimmersion (for ammonia analysis); after $2 \mathrm{~h}$, a haemolymph sample was collected from each mussel (for ammonia and NPS analysis). Five groups of mussels (pooling 20 in each case) were left in each of the test solutions to determine the eventual lethal ammonia level for the mussels during a short period of exposure and to record behavioural changes of the mussels.

The total ammonia $\left(\mathrm{NH}_{4}-\mathrm{N}\right)$ occurs in solution as 2 forms, ammonia ion $\left(\mathrm{NH}_{4}{ }^{+}\right)$and non-ionised ammonia $\left(\mathrm{NH}_{3}\right)$. The relative concentrations of these 2 forms are $\mathrm{pH}$-dependent, as described by the following equilibrium expression:

$$
K_{a}=\frac{\left[\mathrm{NH}_{3}\right]\left[\mathrm{H}^{+}\right]}{\left[\mathrm{NH}_{4}^{+}\right]}
$$

The relative concentrations of the 2 forms are also temperature-dependent, as indicated by the following expression from Emerson et al. (1975) for the temperature dependence of $K_{a}$ (acid dissociation constant):

$$
\mathrm{p} K_{a}=0.09018+2729.92 /(273.2+T)
$$

where $T$ is the temperature in ${ }^{\circ} \mathrm{C}$. Thus the concentrations of $\mathrm{NH}_{3}$ and $\mathrm{NH}_{4}{ }^{+}$were calculated according to the equation of Henderson-Hasserbatch (cited in Morris 1991):
Table 1. Characteristics of the test solutions used

\begin{tabular}{|lccc|}
\hline $\mathrm{pH}$ & $\mathrm{NH}_{4}-\mathrm{N}(\mathrm{mM})$ & $\mathrm{NH}_{3}(\mathrm{mM})$ & $\mathrm{NH}_{4}{ }^{+}(\mathrm{mM})$ \\
\hline 8.2 & 0 & 0 & 0 \\
8.05 & 3.2 & 0.065 & 3.134 \\
7.95 & 6 & 0.098 & 5.901 \\
7.85 & 10 & 0.130 & 9.869 \\
7.65 & 50 & 0.412 & 49.587 \\
7.4 & 100 & 0.465 & 99.534 \\
\hline
\end{tabular}

$$
\mathrm{pH}=\mathrm{p} K_{\mathrm{a}}+\log \left(\left[\mathrm{NH}_{3}\right] /\left[\mathrm{NH}_{4}{ }^{+}\right]\right)
$$

The $\left[\mathrm{NH}_{3}\right]$ can be calculated as follows:

$$
\left[\mathrm{NH}_{3}\right]=\frac{\left[\mathrm{NH}_{3}\right]+\left[\mathrm{NH}_{4}^{+}\right]}{1+10^{(\mathrm{p} K-\mathrm{pH} i)}}
$$

(Armstrong et al. 1978). From the calculated value of $\left[\mathrm{NH}_{3}\right]$, the appropriate value of $\mathrm{pNH}_{3}$ was obtained:

$$
\mathrm{pNH}_{3}=\left[\mathrm{NH}_{3}\right] \times(22.09 / \alpha)
$$

where $\alpha$ is the Busen solubility coefficient $=1.46$ given by Washburne (1928, cited in Kormanik \& Cameron 1981b), $\mathrm{pNH}_{3}=$ potential pressure of $\mathrm{NH}_{3}$ ( $\mu$ torr), and $\left[\mathrm{NH}_{3}\right]=$ concentration of $\mathrm{NH}_{3}\left(\mu \mathrm{mol} \mathrm{l}^{-1}\right)$

At the end of each experiment, the soft body tissue of each Mytilus edulis was removed from the shell, dried at $90^{\circ} \mathrm{C}$ overnight and then weighed. All physiological responses were calculated as weight-specific values on a per gram dry weight $\left(\mathrm{g}^{-1} \mathrm{dw}\right)$ basis.

Haemolymph ammonia and NPS analysis. Samples were thawed and centrifuged for $7 \mathrm{~min}$ at $7000 \times g$ and were then divided into equal volumes $(0.5 \mathrm{ml})$ for NPS (Aliquot 1) and $\mathrm{NH}_{4}-\mathrm{N}$ (Aliquot 2) analysis. Flow injection analysis (Hunter \& Uglow 1993) was used for the total $\mathrm{NH}_{4}-\mathrm{N}$ determination. The NPS measurement was based on a widely used reaction for the determination of amino acids involving heating the sample with ninhydrin. In this context amino acids thus refer to total NPS (Hawkins \& Hilbish 1992). Here, the method was developed for the release of the amino group from the ninhydrin-amino acid complex (Sadok et al. 1995) which enables the released ammonia to be measured using FIA.

Thus, $0.5 \mathrm{ml}$ of sample (Aliquot 1) (and alanine standards; ranging from 5 to $50 \mu \mathrm{mol} \mathrm{l}^{-1}$ ) in a $20 \times 200 \mathrm{~mm}$ test tube was mixed with $1 \mathrm{ml}$ ninhydrin $(3 \mathrm{~g}$ in $100 \mathrm{ml}$ Ultrapure water) and heated in a boiling water bath for $12 \mathrm{~min}$. Then, $1 \mathrm{ml} 0.8 \mathrm{~N} \mathrm{HCl}$ was added before capping the tubes with parafilm (Parafilm $M$ ) and heating for a further $10 \mathrm{~min}\left(100^{\circ} \mathrm{C}\right)$. The released $\mathrm{NH}_{4}$ - $\mathrm{N}$ was measured by injecting $0.3 \mathrm{ml}$ aliquots into the flow injection manifold. The exact value for sample NPS was calculated by subtracting the ammonia in Aliquot 1 from that in Aliquot 2. 
Where appropriate, normally distributed data ( $\mathrm{p}>0.05, \mathrm{~K}-\mathrm{S}$ Lilliefors test) on flux rates, ammonia and NPS concentrations were subjected to Analysis of Variance (1-way ANOVA) using SPSS (Subprogram of the statistical Package for the Social Sciences) on a personal computer. The level of significance for the $F$-test used in conjunction with ANOVA variance data was at the $95 \%$ level of confidence.

\section{RESULTS}

The daily mean ammonia efflux rates of a control group of mussels $(n=6)$ kept in normal seawater throughout the experimental period were measured. No significant deviations amongst these daily means were found $(p>0.05,1$-way ANOVA) and the control mean efflux rate was $0.64 \pm 0.03 \mu \mathrm{mol} \mathrm{g}^{-1} \mathrm{dw} \mathrm{h}^{-1}$.

Expt 1 showed that the $1 \mathrm{~h}$ post-exposure mean ammonia flux rates in the groups of exposed pooled mussels were strongly dependent on the dissolved ammonia concentration in the medium. Only the animals exposed to $20 \mu \mathrm{mol} \mathrm{l} \mathrm{l}^{-1} \quad \mathrm{NH}_{4}-\mathrm{N}$ showed an ammonia efflux; all the other groups showed an ammonia influx (Fig. 1). Over the following $48 \mathrm{~h}$, all groups survived and showed apparently normal pumping behaviour.

The $\mathrm{NH}_{4}$ - $\mathrm{N}$ tolerance was investigated further using more concentrated ammonia-enriched solutions. It was possible to measure net $\mathrm{NH}_{4}-\mathrm{N}$ influx indirectly, with

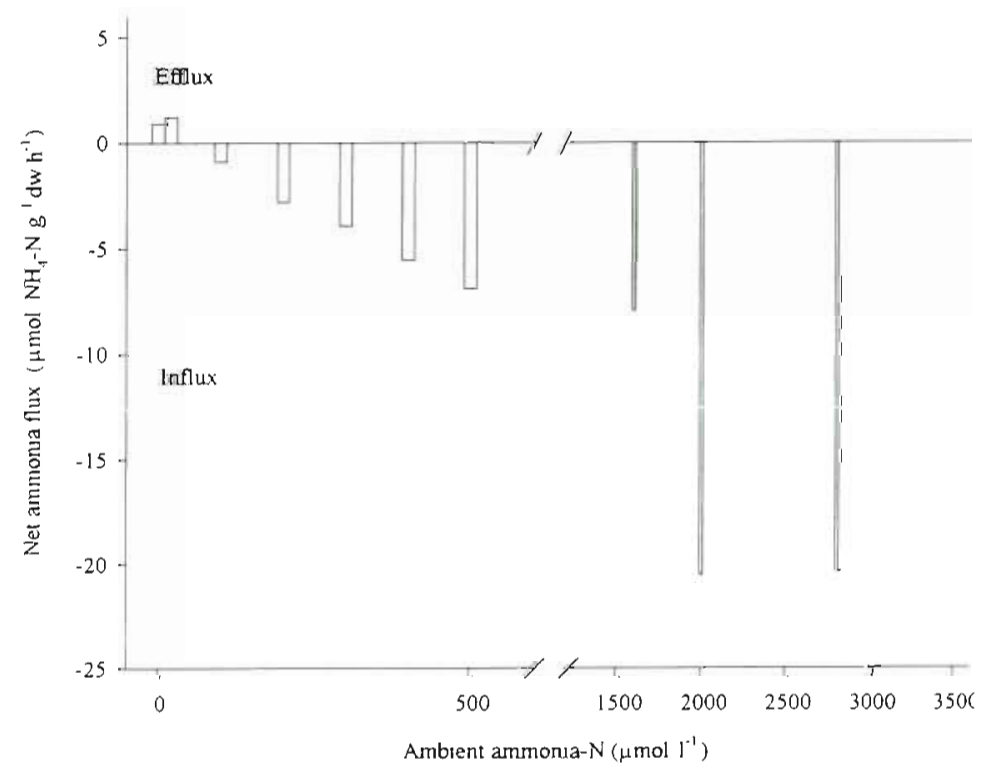

Fig. 1. Mytilus edulis. Weight-specific ammonia flux of pooled mussels ( $n=20$ in each concentration) exposed to different ambient ammonia levels

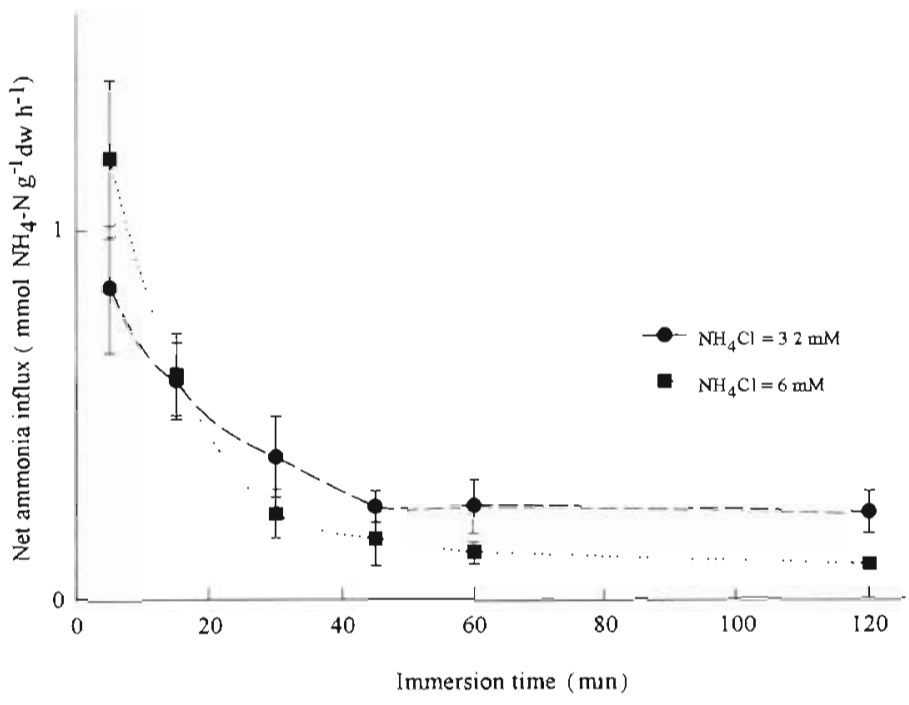

Fig. 2. Mytilus edulis. Weight-specific ammonia influxes as a function of immersion time. Values are given as means $\pm S E$ of $n=6$ mussels in each case

mussels kept in test solutions up to $6 \mathrm{mM} \mathrm{NH}_{4}-\mathrm{N}$, by measuring the progressive loss of $\mathrm{NH}_{4}-\mathrm{N}$ from the solutions (Fig. 2). In the more concentrated solutions, such losses were indetectable because of the relative disparity between the small amount taken up by the mussel and the large amount of ammonia present in the test solutions (ammonia $>6 \mathrm{mM}$ ).

In the more concentrated test solutions (50 and $100 \mathrm{mM} \mathrm{NH}_{4}-\mathrm{N}$ ), the mussels showed a clear pattern of interrupted pumping which presumably also signified a disrupted pattern in their normal metabolism. After $6 \mathrm{~h}$ of exposure, appreciable mortality $(50 \%)$ occurred only within the $100 \mathrm{mM} \mathrm{NH}_{4}-\mathrm{N}$-treated group.

Ammonia uptake during exposure to $\mathrm{NH}_{4}$ $N$-enriched media was also evident from the data on blood $\mathrm{NH}_{4}-\mathrm{N}$ and NPS levels in the experimental and control mussels. The control group had a mean haemolymph level of $1.52 \mu \mathrm{mol} \mathrm{NH}_{4}-\mathrm{N} \mathrm{ml}^{-1} \mathrm{~g}^{-1} \mathrm{dw}$. The treated groups rapidly showed higher mean values $(p<0.05)$ than the control group. The curves shown in Fig. 3a illustrate a gradual increase of haemolymph ammonia concentrations, with a plateau effect occurring after ca 45 min. Contrastively, the haemolymph NPS changes in the $100 \mathrm{mM} \mathrm{NH} \mathrm{NH}_{4} \mathrm{~N}$-treated group diverge widely from those of the other groups (Fig. 3b).

The haemolymph $\mathrm{NH}_{4}-\mathrm{N}$ changes were estimated at various exposure times and these data revealed a linear relationship between the $5 \mathrm{~min}$ exposure values and the 

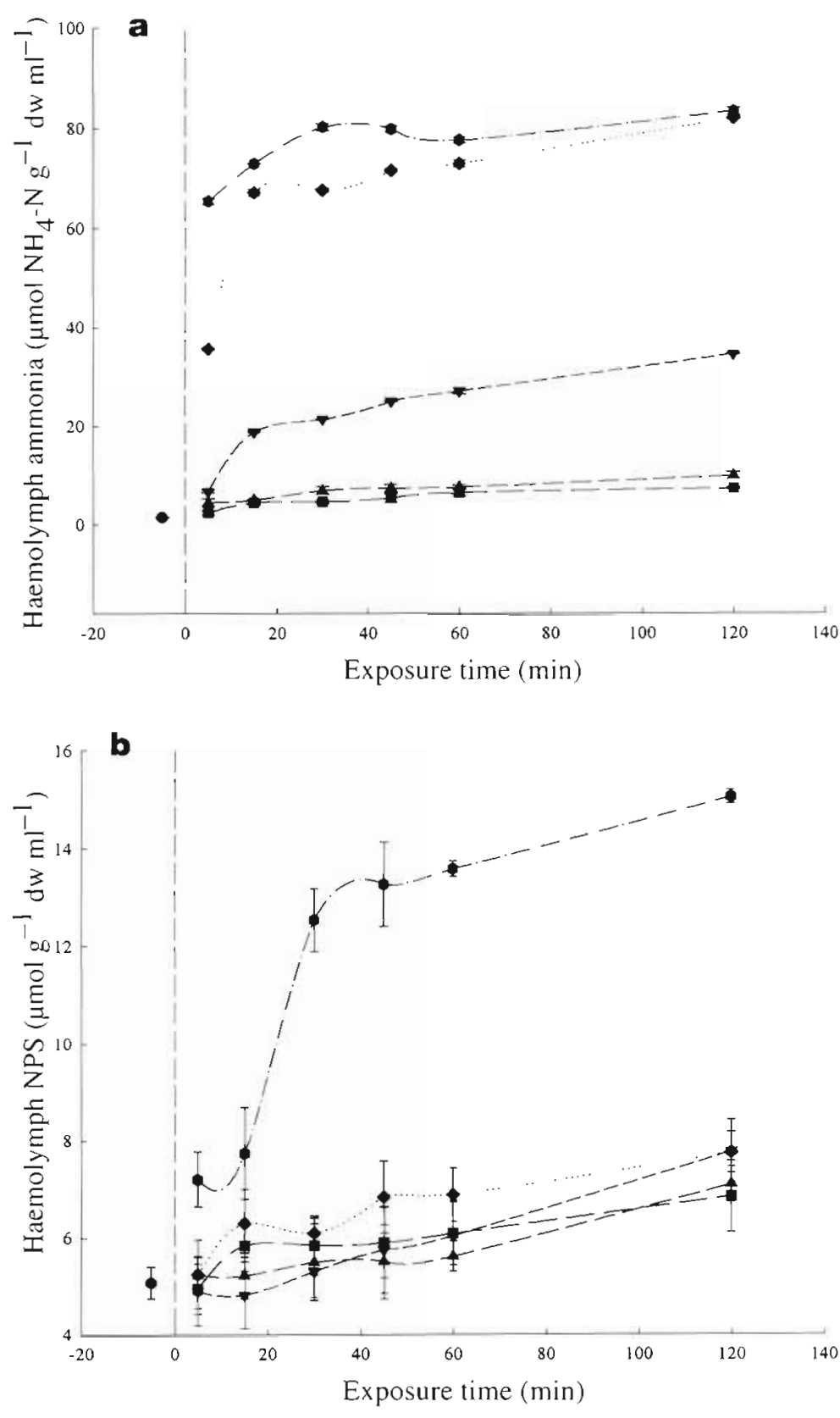

Fig. 3. Mytilus edulis. Mean (a) haemolymph ammonia concentrations and (b) haemolymph NPS concentrations of mussels as a function of time exposed to ammonia-enriched seawater ( $34 \mathrm{psu}$ ). Data for the control group represent (a) the $\mathrm{NH}_{4}-\mathrm{N}$ levels, (b) the mean NPS levels, over $2 \mathrm{~h}$ of immersion. Vertical

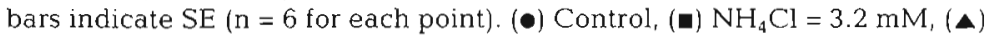
$\mathrm{NH}_{4} \mathrm{Cl}=6 \mathrm{mM},(\nabla) \mathrm{NH}_{4} \mathrm{Cl}=10 \mathrm{mM}^{\prime}(\bullet) \mathrm{NH}_{4} \mathrm{Cl}=50 \mathrm{mM},(\bullet) \mathrm{NH}_{4} \mathrm{Cl}=$ $100 \mathrm{mM}$

experimental $\mathrm{NH}_{4}-\mathrm{N}$ concentrations, and that the 5 min exposure blood NPS levels were indetectable at test concentrations $<40 \mathrm{mM}$ ambient $\mathrm{NH}_{4}-\mathrm{N}$ (Fig. 4a). After 5 min had elapsed, all mussels in test solutions $10 \mathrm{mM} \mathrm{NH} \mathrm{NH}_{4}-\mathrm{N}$ had adducted their valves and the 15 min haemolymph $\mathrm{NH}_{4}-\mathrm{N}$ and $\mathrm{NPS}$ values were essentially the same as those measured after 5 min exposure (Fig. 4b). At $30 \mathrm{~min}$ exposure, all mussels except those in $100 \mathrm{mM} \mathrm{NH}-\mathrm{N}$ solution had recommenced pumping; this was accompanied by further increases to their blood ammonia and NPS levels (Fig. 4c). After 45 min, the $50 \mathrm{mM} \mathrm{NH}_{4}-\mathrm{N}$-treated mussels had again all ceased pumping and did not recommence during the experimental period; their blood $\mathrm{NH}_{4}-\mathrm{N}$ and NPS mean values remained essentially the same as their $30 \mathrm{~min}$ values over this time (Fig. 4d-f). However, the other groups continued apparently normal pumping, which was reflected by progressively increased haemolymph blood ammonia and NPS levels (Fig. 4d-f). After 2 h exposure, the circulating NPS levels in the 3.2 and $6 \mathrm{mM} \mathrm{NH}_{4}$-N-treated groups were actually higher than the corresponding haemolymph ammonia levels (Fig. 4f).

The suggestion that Mytilus edulis showed $\mathrm{NH}_{4}-\mathrm{N}$ uptake was tested by comparing the haemolymph $\mathrm{NH}_{4}-\mathrm{N}$ and NPS levels and the $\mathrm{NH}_{4}-\mathrm{N}$ efflux rates of groups exposed to 6 and $10 \mathrm{mM} \mathrm{NH}_{4}-\mathrm{N}$ medium with those reimmersed in $\mathrm{NH}_{4}$ $\mathrm{N}$-free seawater for $2 \mathrm{~h}$ after such treatments. Table 2 shows that before reimmersion, mussels had significantly ( $p<$ 0.05) higher haemolymph $\mathrm{NH}_{4}-\mathrm{N}$ values than the $2 \mathrm{~h}$ reimmersed ones (indicating a very rapid discharge from the mussels). However, even these values were still significantly higher than those of the control groups ( $p<0.05$ in each case). After 2 h of reimmersion, haemolymph NPS of the $6 \mathrm{mM} \mathrm{NH}_{4}$-N-treated group (but not the $10 \mathrm{NH}_{4}-\mathrm{N}$-treated groupl had fallen to the normal NPS levels. The post-reimmersion $\mathrm{NH}_{4}-\mathrm{N}$ efflux rate increases showed a linear relationship with the exposure concentration (Fig. 5).

The water and haemolymph $\mathrm{pH}$ values obtained for some groups of Mytilus edulis are given in Table 3 . An acidosis of the seawater occurred with the strongest $\mathrm{NH}_{4}-\mathrm{N}$ solution used. A slight trend of haemolymph alkalosis was also found as ambient $\mathrm{NH}_{4}$ $\mathrm{N}$ levels increased. One-way ANOVA revealed significant $(\mathrm{p}<0.05$ ) haemolymph $\mathrm{pH}$ differences between the experimental and the control groups.

After $2 \mathrm{~h}$ of post-exposure incubation in normal seawater, haemolymph $\mathrm{NH}_{4}-\mathrm{N}$ levels still remained 

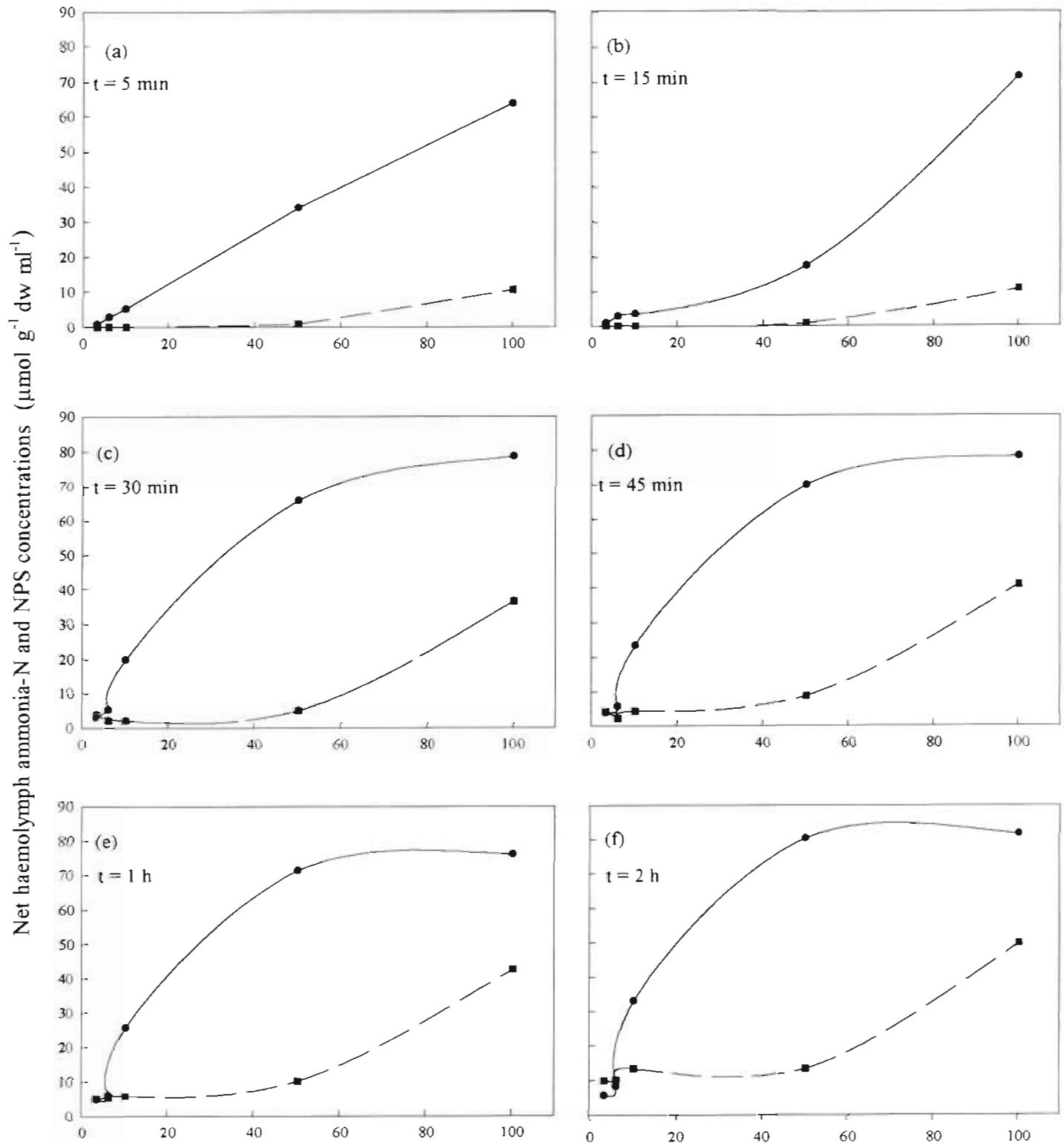

Ambient ammonia- $\mathrm{N}(\mathrm{mM})$

Fig. 4. Mytilus edulis. Time course of change to the net differences between the mean values of haemolymph $\mathrm{NH} \mathrm{A}_{4}-\mathrm{N}(-)$ and

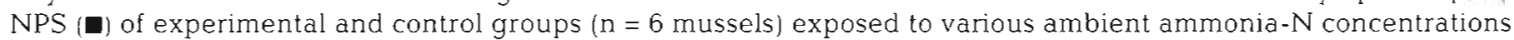

Table 2. Mytilus edulis. Haemolymph ammonia and NPS concentrations of mussels exposed for $2 \mathrm{~h}$ in 6 or $10 \mathrm{mM}$ ambient $\mathrm{NH}_{4}-\mathrm{N}$ and of mussels reimmersed in ammonia-free seawater. Each value is the mean of 6 observations

Experimental conditions

Normal seawater (control group)

Enriched seawater (10 $\left.\mathrm{mM} \mathrm{NH}_{4}-\mathrm{N}\right)(\mathrm{B})$

Mussels from (A) reimmersed in normal seawater

Mussels from (B) reimmersed in normal seawater
Haemolymph $\mathrm{NH}_{4}-\mathrm{N}$ $\left(\mu \mathrm{mol} \mathrm{g}{ }^{-1} \mathrm{dw} \mathrm{ml}^{-1}\right)( \pm \mathrm{SE})$
Haemolymph NPS $\left(\mu \mathrm{mol} \mathrm{g}^{-1} \mathrm{dw} \mathrm{ml}^{-1}\right)( \pm \mathrm{SE})$

$\begin{aligned} 1.52 & \pm 0.052 \\ 9.88 & \pm 0.711 \\ 34.60 & \pm 0.156 \\ 3.24 & \pm 0.198 \\ 5.505 & \pm 0.76\end{aligned}$

$25.36 \pm 0.33$

$35.519 \pm 3.96$

$37.909 \pm 0.65$

$25.78 \pm 1.01$

$33.36 \pm 0.70$ 
higher than those in the bathing medium and this resulted in the high haemolymph:medium $\left[\mathrm{NH}_{3}\right]$ and $\left[\mathrm{NH}_{4}{ }^{+}\right]$ratios given in Table 4 . These ratios were $1: 1$, indicating that the internal $\left[\mathrm{NH}_{3}\right]$ and $\left[\mathrm{NH}_{4}{ }^{+}\right]$become negatively related to the external values on exposure to high $\mathrm{NH}_{4}-\mathrm{N}$ levels

The calculated $\left[\mathrm{NH}_{3}\right]$ and $\left[\mathrm{NH}_{4}{ }^{+}\right]$gradients are also given in Table 4 and reveal that the $\left[\mathrm{NH}_{3}\right]$ gradient

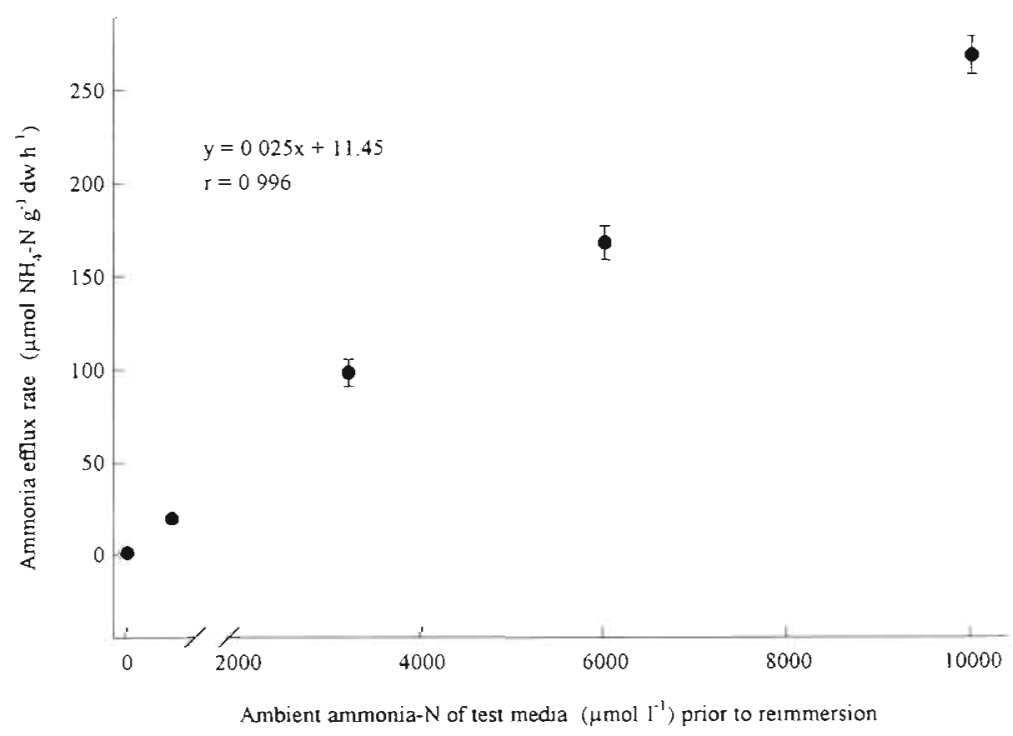

Fig. 5. Mytilus edulis. Ammonia efflux rates following reimmersion in ammonia-free seawater after exposure to ammonia-enriched medium. Each value is the mean $\pm \mathrm{SE}$ of 6 observations was consistently low (cf. the $\left[\mathrm{NH}_{4}^{+}\right]$gradient). The gradients of both decreased with medium $\mathrm{NH}_{4}-\mathrm{N}$ enrichment. The $\left[\mathrm{NH}_{4}{ }^{+}\right]$gradient became negative at around $6 \mathrm{mM}$ ambient $\mathrm{NH}_{4}-\mathrm{N}$ (Table 4). The $\mathrm{pNH}_{3}$ gradient was also found to be negatively related to the external $\mathrm{NH}_{4}$-N levels, and significant within-group differences were found ( $p<0.05,1$-way ANOVA). In the control group, the $\mathrm{pNH}_{3}$ was significantly greater than those of the 3.2 and $6 \mathrm{mM} \mathrm{NH}_{4}-\mathrm{N}$-treated groups ( $p<0.05$, 1-way ANOVA), which suggests a trend of haemolymph $\mathrm{pNH}_{3}$ gradients becoming negatively related to high ambient $\mathrm{NH}_{4}-\mathrm{N}$ levels and thus facilitating $\mathrm{NH}_{3}$ influx.

\section{DISCUSSION}

It is clear from these studies that Mytilus edulis is very tolerant of elevated ambient ammonia levels. The present data reveal that this species can survive acute exposure (up to $10 \mathrm{~h}$ ) to ambient ammonia levels at least as high as $50 \mathrm{mM}$ $\mathrm{NH}_{4}-\mathrm{N}$. This is much higher than the $7.1 \mathrm{mM} \mathrm{NH}_{4}-\mathrm{N}$ which was lethal to shrimp after 8 to $10 \mathrm{~h}$ exposure (Chen 1993). Most fish species are killed at around $20 \mu \mathrm{M} \mathrm{NH} \mathrm{NH}_{4}-\mathrm{N}$ (Campell 1991). Ammonia concentrations in the field vary seasonally and with location (e.g. in the

Table 3. Mytilus edulis. Summary of data obtained on ammonia concentration and $\mathrm{pH}$ of seawater and haemolymph of mussels exposed to test solutions for $2 \mathrm{~h}$. Values are means of observations ( $\pm \mathrm{SE}$ ) in each case

\begin{tabular}{|c|c|c|c|c|}
\hline \multirow[t]{2}{*}{ Experimental conditions } & \multicolumn{2}{|c|}{ Seawater } & \multicolumn{2}{|c|}{ Haemolymph } \\
\hline & Final $\mathrm{NH}_{4}-\mathrm{N}\left(\mu \mathrm{mol} \mathrm{l^{-1 }}\right)$ & Final $\mathrm{pH}$ & Final $\mathrm{NH}_{4}=\mathrm{N}\left(\mu \mathrm{mol} \mathrm{l} \mathrm{l}^{-1}\right)$ & Final pH \\
\hline Control (normal seawater) & $8.155 \pm 0.52$ & $8.20 \pm 0.01$ & $482.53 \pm 29.79$ & $7.035 \pm 0.05$ \\
\hline Enriched seawater (3.2 $\mathrm{mM} \mathrm{NH}_{4}-\mathrm{N}$ ) & $1871.79 \pm 68.11$ & $8.05 \pm 0.01$ & $2024.53 \pm 149.27$ & $7.068 \pm 0.04$ \\
\hline Enriched seawater ( $\left.6 \mathrm{mM} \mathrm{NH}_{4}-\mathrm{N}\right)$ & $5400 \pm 53.93$ & $7.95 \pm 0.03$ & $4047.27 \pm 132.54$ & $7.11 \pm 0.035$ \\
\hline Enriched seawater $\left(10 \mathrm{mM} \mathrm{NH}_{4}-\mathrm{N}\right)$ & $\sim 10^{4}$ & $7.85 \pm 0.02$ & $7349.52 \pm 65.68$ & $7.14 \pm 0.095$ \\
\hline
\end{tabular}

Table 4. Mytilus edulis. Summary of $\left[\mathrm{NH}_{3}\right]$ and $\left[\mathrm{NH}_{4}{ }^{+}\right]$in haemolymph and seawater and their haemolymph:medium ratios and gradients of $\mathrm{NH}_{3}$ and $\mathrm{NH}_{4}{ }^{+}$Values are given as mean for $\mathrm{n}=6$ individuals in each case

\begin{tabular}{|c|c|c|c|c|c|c|c|}
\hline \multirow[t]{2}{*}{ Experimental conditions } & \multicolumn{2}{|c|}{ Ammonia haemolymph } & \multicolumn{2}{|c|}{$\begin{array}{l}\text { Haemolymph:medium } \\
\text { ratio of: }\end{array}$} & \multicolumn{2}{|c|}{ 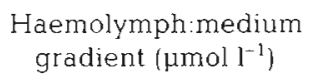 } & \multirow{2}{*}{ 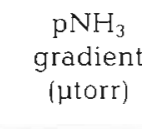 } \\
\hline & $\left(\mu \mathrm{mol} \mathrm{l}^{-1}\right)$ & $\left(\mathrm{umol} \mathrm{l}^{-1}\right)$ & {$\left[\mathrm{NH}_{3}\right]$} & {$\left[\mathrm{NH}_{4}{ }^{+}\right]$} & {$\left[\mathrm{NH}_{3}\right]$} & {$\left[\mathrm{NH}_{4}{ }^{4}\right]$} & \\
\hline Normal seawater control & 0.97 & 481.55 & $4.21: 1$ & $60.34: 1$ & +0.74 & 473.62 & +11.19 \\
\hline Enriched seawater $\left(3.2 \mathrm{mM} \mathrm{NH}_{4}-\mathrm{N}\right)$ & 4.40 & 2020.12 & $0.11: 1$ & $1.10: 1$ & -33.93 & +186.67 & -513.36 \\
\hline Enriched seawater $\left(6 \mathrm{mM} \mathrm{NH}_{4}-\mathrm{N}\right)$ & 9.69 & 4037.57 & $0.10: 1$ & $0.76: 1$ & -78.51 & -1274.22 & -1187.86 \\
\hline
\end{tabular}


central North Sea a $1 \mu \mathrm{g} \mathrm{l}^{-1}$ bottom water ammonia level measured in February rose to $3 \mu \mathrm{g} \mathrm{l}^{-1}$ in May; Brockman et al. 1988). However, in situ ammonia concentrations can reach $7.8 \%$ ammonia in sewage sludge input to the North Sea (Parker 1988) or as high as 15.83 $\mathrm{g} \mathrm{m}^{-3} \mathrm{~d}^{-1}$ in the water discharged from shrimp farms (Enander \& Hasselstron 1994).

The mean weight-specific efflux rates of Mytilus edulis found in this study varied between $0.64 \mu \mathrm{mol} \mathrm{h}^{-1}$ $\mathrm{g}^{-1} \mathrm{dw}$ for the control group to $0.90 \mu \mathrm{mol} \mathrm{h}{ }^{-1} \mathrm{~g}^{-1} \mathrm{dw}$ for mussels exposed to media containing $20 \mu \mathrm{mol} \mathrm{NH}_{4}{ }^{-}$ $\mathrm{N}^{-1}$. The control values are within the range given for $M$. edulis in normal seawater (Bayne \& Scullard 1977, Widdows \& Shick 1985) but an exact comparison is complicated by the wide variation in the extent of ammonia losses generally shown by bivalves (Bishop et al. 1983, Tedengren \& Kautsky 1987). These studies show that the ammonia- $N$ excretion of $M$. edulis increased directly with ambient ammonia concentration over the range 0 to $20 \mu \mathrm{M} \mathrm{NH}_{4}-\mathrm{N}$. Similar results were found by Chen et al. (1994) for Penaeus monodon. At ambient concentrations $\geq 100 \mu \mathrm{M}$, a net ammonia uptake occurred after $1 \mathrm{~h}$ of exposure and during the following $1 \mathrm{~h}$ of treatment. In contrast to the findings on other species (e.g. Hosie et al. 1991), an apparent ammonia influx was found here with $M$. edulis exposed for only $5 \mathrm{~min}$ in seawater containing 3.2 or $6 \mathrm{mM} \mathrm{NH}_{4}-\mathrm{N}$. The influx rates pertaining to $5 \mathrm{~min}$ were relatively higher $(p<0.05)$ than those measured during the following $2 \mathrm{~h}$, as shown in Fig. 2 .

When abruptly transferred from their holding tank to their individual containers, all mussels were seen to show an initial period (minutes) of shell gape, even when the medium was ammonia-enriched. Such behaviour would allow an ammonia influx to occur and probably explains the initial high influx rates that were recorded.

The mean blood ammonia concentration found (Table 3) was $482.53 \mu \mathrm{mol} \mathrm{NH}_{4}-\mathrm{N} \mathrm{l}^{-1}$, which accords with the seasonal range of 171.93 to $992.00 \mu \mathrm{mol} \mathrm{NH}_{4}$ $\mathrm{N}^{-1}$ given for Mytilus edulis (Bayne 1973a) and is similar to the haemolymph ammonia level of $2 \mathrm{mM} \mathrm{NH}_{4}-\mathrm{N}$ for Rangia cuneata (Mangum et al. 1978) and the 500 to $600 \mu \mathrm{mol} \mathrm{NH}{ }_{4}-\mathrm{N} \mathrm{I}^{-1}$ for Modiolus demissus (Bartberger \& Pierce 1976). M. edulis exposed to supranormal concentrations of ambient ammonia had blood ammonia levels significantly higher than normal $(p<0.05)$. A linear, negative relationship between blood ammonia concentration and rate of $\mathrm{NH}_{4}-\mathrm{N}$ influx in $M$. edulis exposed to $3.2 \mathrm{mM} \mathrm{NH}_{4}-\mathrm{N}$ was found $(\mathrm{r}=-0.911, \mathrm{p}<$ $0.05)$, which suggests a priori a passive diffusion of ammonia into the mussel along a downhill gradient in order to reach a state of equilibrium.

Such diffusion may occur through aqueous channels that penetrate the lipid bilayer of the gill epithelium, or simply across the thickness of the lipid or protein layer. Because of its small size and neutrality, $\mathrm{NH}_{3}$ was long considered to be the main form which freely permeates the gill epithelium. Several works have now demonstrated the permeation by both the ionic and non-ionic forms (Goldstein et al. 1982, Cameron 1986, Regnault 1987, Wilson et al. 1994). According to Cameron (1986), the mode of diffusion varies interspecifically, but there is a general paucity of data relating to molluscs in general or mussels in particular.

If ammonia flux occurred as a continuous diffusion of gas across the membrane, induced by the continuous readjustment of the relative proportions of $\mathrm{NH}_{3}$ and $\mathrm{NH}_{4}{ }^{+}$constituting the ambient ammonia, one would expect a linear increase in haemolymph ammonia until equilibrium is reached between the 2 media. However, the present findings did not always conform to this prediction. When exposed to $6 \mathrm{mM} \mathrm{NH}_{4}-\mathrm{N}$, the linear relationship between ammonia uptake and haemolymph $\mathrm{NH}_{4}-\mathrm{N}$ found for mussels immersed in $3.2 \mathrm{mM} \mathrm{NH}_{4}-\mathrm{N}$ was attenuated and resulted in an asymptotic curve (Fig. 6). Such curves may be taken as an evidence of a rate-limiting step in the permeation process (Eckert \& Randall 1983) and suggest that the passive permeation of ionic $\mathrm{NH}_{4}{ }^{+}$is an alternative to that of the base $\left(\mathrm{NH}_{3}\right)$ form. Such ionic permeation could indicate either (1) a binding of $\mathrm{NH}_{4}{ }^{+}$to molecules lined along the permeating channels (hence the diffusion of $\mathrm{NH}_{4}{ }^{+}$is retarded by the kinetics of the binding stepl or (2) that $\mathrm{NH}_{4}{ }^{+}$is carried by some carrier molecule(s) free to diffuse within the

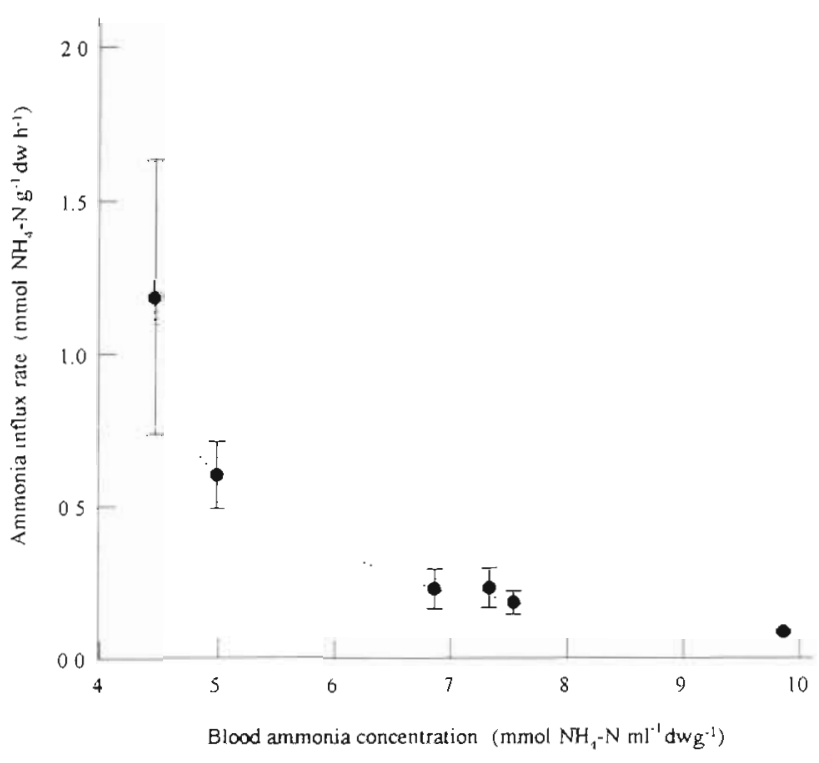

Fig. 6. Mytilus edulis. Relationship between the ammona uptake rate and the blood ammona concentration of mussels exposed to $6 \mathrm{mM}$ ambient ammonia for $2 \mathrm{~h}$. Vertical bars represent the $\mathrm{SE}$ of $\mathrm{n}=6$ in each case 
membrane, from one side to the other, thus facilitating the passage of $\mathrm{NH}_{4}{ }^{+}$. Since the number of carrier molecules and the rate at which they react with and traverse the membrane must be finite, the rate of carriermediated $\mathrm{NH}_{4}{ }^{+}$transport will reach a maximum when all the carrier molecules are occupied by $\mathrm{NH}_{4}{ }^{+}$, as the plateau observed in the curve (Fig. 6). This facilitated transport may be confused with active transport, which exhibits Michaelis-Menten kinetics.

It has been shown that marine fish (Wilson \& Taylor 1992) and crustaceans (Cameron 1986, Hosie et al. 1991) are able to maintain reversed $\mathrm{pNH}_{3}$ and $\mathrm{NH}_{4}{ }^{+}$ gradients when external levels are elevated. In these cases, it was concluded that some form of active $\mathrm{NH}_{4}{ }^{+}$ extrusion must be operating in order to counteract an inward diffusion of $\mathrm{NH}_{3}$ and $\mathrm{NH}_{4}{ }^{+}$. Our results showed that haemolymph ammonia increased, but to levels lower than external ambient levels in all the groups except that exposed to $3.2 \mathrm{mM} \mathrm{NH}_{4}-\mathrm{N}$. These haemolymph ammonia concentrations were far below levels consistent with passive equilibrium. The $\mathrm{pNH}_{3}$ gradient started to become negative on exposure to external ammonia levels $\geq 3.2 \mathrm{mM}$, which suggests that when a threshold, internal $\mathrm{NH}_{4}-\mathrm{N}$ load is exceeded (blood $\mathrm{NH}_{4}-\mathrm{N} 2.0 \mathrm{mM}$ ), an active pump functioning to extrude $\mathrm{NH}_{4}{ }^{+}$operates to mitigate increased diffusional influx. This extrusion of $\mathrm{NH}_{4}{ }^{+}$may be coupled to an influx of $\mathrm{Na}^{+}$, and many studies have provided supporting evidence for a carrier-mediated $\mathrm{Na}^{+} / \mathrm{NH}_{4}{ }^{+}$ exchange in marine or $\mathrm{H}^{+} / \mathrm{NH}_{4}{ }^{+}$in freshwater species (Maetz 1973, Cameron 1986, Regnault 1987, Wilson \& Taylor 1992). Unfortunately, apart from the investigations of Mangum et al. (1978), data on the mechanism of ammonia fluxes in molluscs are limited. Mangum et al. (1978) used metabolic inhibitors (ouabain) to show that the ammonia output of bivalves such as Rangia sp. involves a putative $\mathrm{Na}^{+} / \mathrm{NH}_{4}{ }^{+}$exchange.

If gill epithelia were permeable only to $\mathrm{NH}_{3}$, then the haemolymph $\mathrm{pH}$ would rise and level off during ammonia exposure. Instead, the rapid initial rise in internal $\mathrm{pH}$ measured at 5 and 15 min post- $\mathrm{NH}_{4}-\mathrm{N}$ exposure (Fig. 7) was followed by a slow decrease in $\mathrm{pH}$ over the following $2 \mathrm{~h}$. This indicates that the $\mathrm{NH}_{3}$ taken up rapidly protonates to form $\mathrm{NH}_{4}{ }^{+}$and thereby produces an alkalosis. This process may be attenuated as $\mathrm{NH}_{4}{ }^{+}$is also taken up slowly and dissociates to form $\mathrm{NH}_{3}$ and $\mathrm{H}^{+}$, thus provoking a relatively slow decrease in $\mathrm{pH}$ (Fig. 8). Such an acidifying effect on the cellular $\mathrm{pH}$ has been demonstrated in snails when iontophoretically injected with $\mathrm{NH}_{4}^{+}$(Thomas 1974).

Ammonia may enter the blood of ammonotelic species via metabolic processes or by influx from elevated ambient ammonia levels. The blood $\mathrm{NH}_{4}-\mathrm{N}$ concentrations tolerated and the attendant detoxification mechanisms elaborated offer a means of assessing the

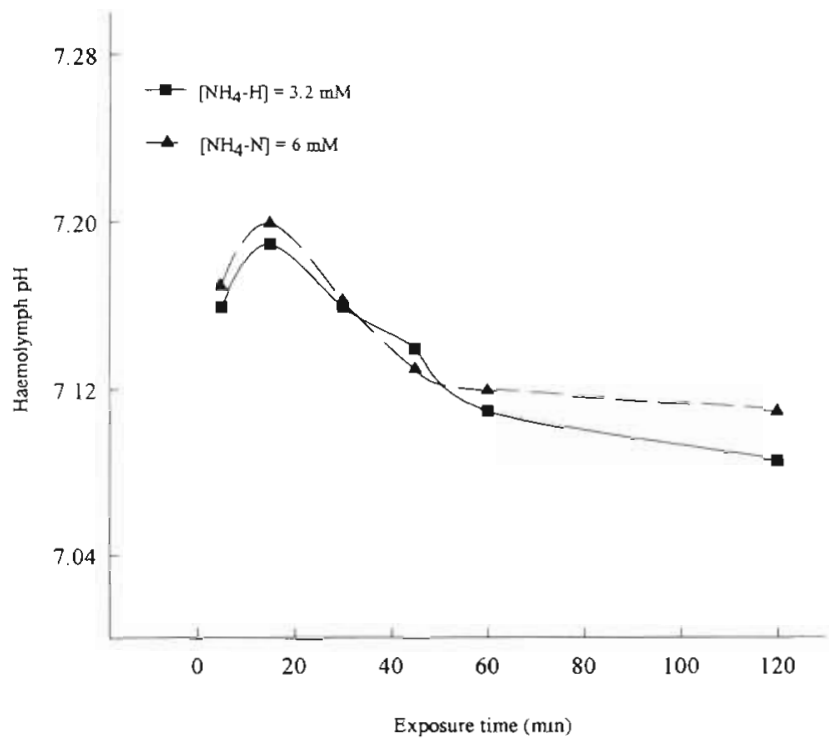

Fig. 7. Mytilus edulis. Haemolymph pH of mussels as a function of exposure time. Values are the means of $n=6$ mussels in each case

ability of the species to respond to such stress. But shell valve adduction (preventing influxes) and haemolymph acidosis (promoting toxic $\mathrm{NH}_{3}$ effluxes) may not be the only means by which Mytilus edulis resists the stresses of high ambient ammonia. The species is able to respire anaerobically and this favours direct ammonia fixation which leads to the synthesis of some amino acids (Zurburg \& Zwaan 1981, Demers \& Guderley 1994), thereby preventing a high ammonia accumulation. Here, measurable increases in haemolymph NPS levels were found in all groups exposed to ammoniaenriched media (Fig. 4c).

The delay between the start of exposure and the increase in haemolymph NPS levels may be related to the pertaining ambient ammonia level and thus the rate of haemolymph $\mathrm{NH}_{4}-\mathrm{N}$ increase. The NPS increases suggest a possible role of these amino acids in the sequestration and detoxification of accumulating ammonia. When reimmersed in normal seawater after exposure to 3.2 or $6 \mathrm{mM} \mathrm{NH}_{4}-\mathrm{N}$ Mytilus edulis showed a pronounced ammonia efflux and a concomitant decrease in the haemolymph NPS pool, indicating that such effluxes include the products of active deamination of the amino acids accumulated in response to supranormal ammonia loading.

When Mytilus edulis were exposed to $\mathrm{NH}_{4}-\mathrm{N}>$ $50 \mathrm{mM}$, they rapidly (within $5 \mathrm{~min}$ of exposure) showed haemolymph NPS levels significantly higher than control or other experimental groups $(p<0.05$, in all cases). These data suggest an altered metabolism of the mussel and may indicate the production of FAA as a shock response, or may also indicate an altered pro- 

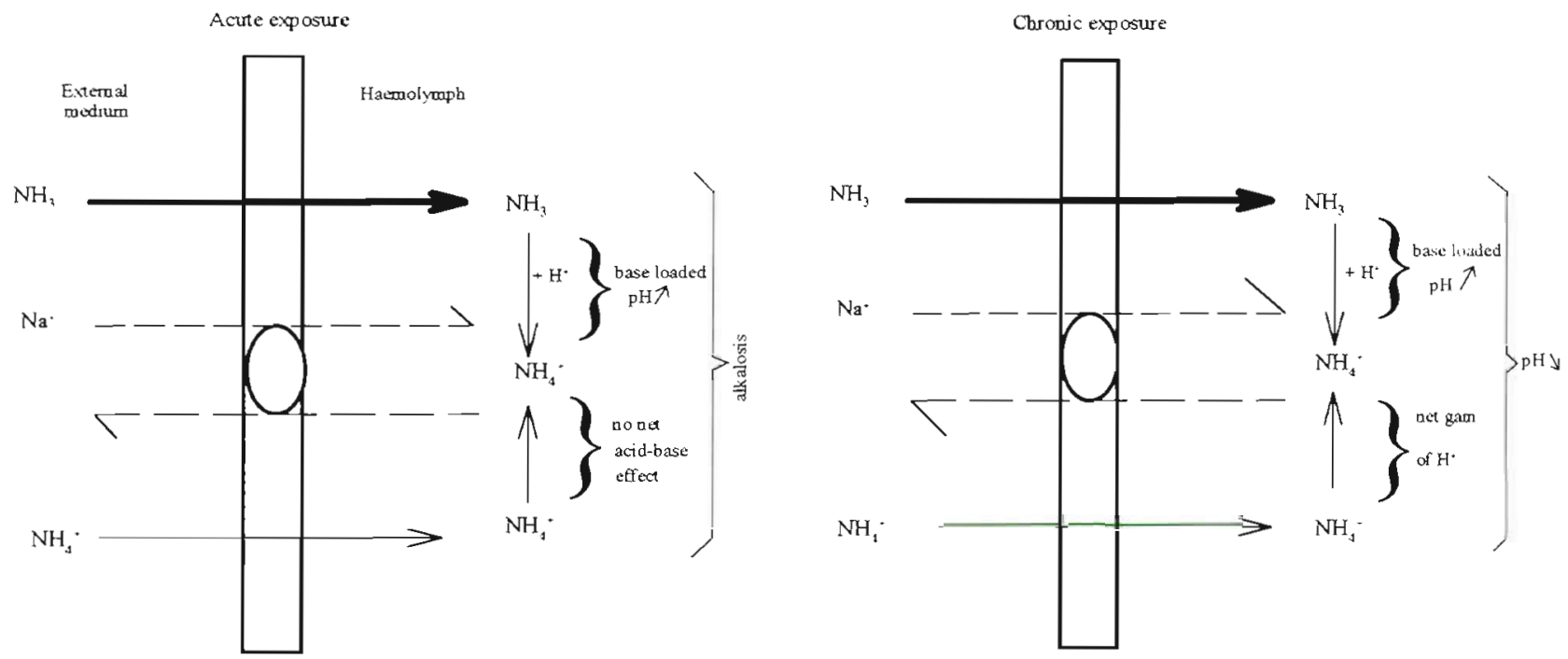

Fig. 8. Effect of ionic ammonia permeation on haemolymph pH (modified from Wilson \& Taylor 1992). Vertical open bar: epithelial membrane. Horizontal arrows: diffusion, thickness of the arrows relates to their relative contribution; half arrows: carriermediated exchange transport

tein synthesis. Such conclusions were also drawn by Chen et al. (1994) on the basis of his data relating to Penaeus sp.

Although Mytilus edulis was found to withstand high ammonia levels, its ability to cope with a simultaneous, in situ oxygen deficiency (due to eutrophication) and a relatively high dissolved ammonia concentration still needs to be investigated, as hypoxia and ammonia enrichment were found to increase total amino acid levels in the body, the consequences of which are unknown.

These studies are being extended to determine the activities of enzymes involved in the nitrogen metabolism of Mytilus edulis exposed to ammonia enrichment and also to determine the effect of such exposure on growth rates of this species.

\section{LITERATURE CITED}

Armstrong D, Chippendale D, Knight AW, Colt JE (1978) Interaction of ionized and unionized ammonia on shortterm survival and growth of prawn larvae, Macrobrachium rosenbergii. Biol Bull mar bıol Lab, Woods Hole $154: 15-31$

Bartberger CA, Pierce SK (1976) Relationship between ammonia excretion rates and haemolymph nitrogenous compound of a euryhaline bivalve dunng low salinity acclimatisation. Biol Bull mar biol Lab. Woods Hole 150:1-14

Bayne BL (1973a) Physiological changes in Mytilus edulis $\mathrm{L}$. induced by temperature and nutritive stress. $J$ mar biol Ass UK 53:39-58

Bayne BL (1973b) Aspects of the metabolism of Mytllus edulis dunng starvation. Neth J Sea Res 7:399-410

Bayne BL (1976) Marine mussels: their ecology and physiology. Cambridge University Press, London
Bayne BL, Scullard C (1977) Rates of nitrogen excretion by species of Mytilus (Bivalvia: Mollusca). J mar biol Ass UK 57:355-369

Bishop SH, Ellis LL, Burcham JM (1983) Amino acid metabolism. In: Hochachka PW (ed) The Mollusca. Metabolic biochemistry and molecular biomechanics, Vol 1 Academic Press, New York, p 234-327

Boucher G, Redoni RB (1988) In situ measurement of respiratory metabolism and nitrogen fluxes at the interface of an oyster bed. Mar Ecol Prog Ser 44:222-238

Brockmann U, Billen G, Gieskes WWC (1988) North Sea nutrients and eutrophication. In: Salomons W. Duursma EK, Bayne BL, Förstner U (eds) Pollution of the North Sea. An assessment. Springer-Verlag, Berlin, p 348-389

Cameron JN (1986) Responses to reversed $\mathrm{NH}_{3}$ and $\mathrm{NH}_{4}{ }^{+}$gradients in a teleost (Ictalurus punctatus), an elasmobranch (Raja erinacea) and a crustacean (Callinectes sapidus): evidence for $\mathrm{NH}_{4}^{+} / \mathrm{H}^{+}$exchanges in the teleost and elasmobranch. J exp Zool 239:183-195

Campell JW (1991) Excretory nitrogen metabolism. In: Prosser L (ed) Environmental animal physiology, comparative animal physiology, 4 th edn. Wiley-Liss, New York, $p$ $277-324$

Chen JC (1993) Accumulation of ammonia in the haemolymph of Penaeus monodon exposed to ambient ammonia. Aquaculture 109:177-185

Chen JC, Chen CT, Cheng SY (1994) Nitrogen excretion and changes of hemocyanin, protein and tree amino acid levels in the hemolymph of Penaeus monodon exposed to different concentrations of ambient ammonia- $\mathrm{N}$ at different salinity levels. Mar Ecol Prog Ser 110:85-94

Costello MJ, Fretwell K, Read P (1993) Toxicity of sewage sludge to Crangon crangon and Artemia salina, with reference to other marine crustacea. Aquat Living Resour 6 $351-356$

Crowe JH (1981) Transport of exogenous substrate and cell volume regulation in bivalve molluscs. J exp Zool 215 $363-370$

Dame RF, Dankers N (1988) Uptake and release of matenals by a Wadden Sea mussel bed. J exp mar Biol 118:207-216 
Demers A, Guderley H (1994) Acclimatization to intertidal conditions modifies the physiological response to prolonged air exposure in Mytilus edulis. Mar Biol 118:115-122

Eckert R, Randall D (1983) Animal physiology: mechanisms and adaptations, 2nd edn. WH Freeman \& Co, San Francisco, p $537-540$

Emerson K, Russo RC, Lund RE, Thurstein RV (1975) Aqueous ammonia equilibrium calculation: effect of $\mathrm{pH}$ and temperature. J Fish Res Bd Can 32:2379-2383

Enander M, Hasselstron M (1994) An experimental waste water treatment system for a shrimp farm. Infofish Int FAO $4: 56-61$

Goldstein L, Claiborne JB, Evans DH (1982) Ammonia excretion by the gills of 2 marine teleost fishes: the importance of $\mathrm{NH}_{4}{ }^{+}$permeance. $\mathrm{J}$ exp Zool 219:395-397

Hatcher A, Grant J, Schofield B (1994) Effects of suspended mussel culture (Mytilus spp.) on sedimentation, benthic respiration and sediment nutrient dynamics in a coastal bay. Mar Ecol Prog Ser 115:219-235

Hawkins AJS, Bayne BL (1992) Physiological interrelations and the regulation of production. In: Gosling $E(e d)$ The mussel, Mytilus: ecology, physiology, genetics and culture. Elsevier, p 179-222

Hawkins AJS, Hilbish TJ (1992) The cost of cell volume regulation: protein metabolism during hyperosmotic adjustment. J mar biol Ass UK 72:569-578

Hosie DA, Uglow RF, Hagerman L, Sondergaard T, Weile K (1991) Some effects of hypoxia and medium ammonia enrichment on efflux rates and circulating levels of ammonia in Nephrops norvegicus. Mar Biol 110:273-279

Hunter DA, Uglow RF (1993) A technique for the measurement of total ammonia in small volumes of seawater. Ophelia 37 (1):31-40

Jorgensen CB (1983) Patterns of uptake of dissolved amino acids in mussels (Mytilus edulis). Mar Biol 73:177-182

Kormanik GA, Cameron JN (1981a) Ammonia excretion in the seawater crab (Callinectes sapidus) occurs by diffusion, and not $\mathrm{Na}^{+} / \mathrm{NH}_{4}{ }^{+}$exchange. J Comp Physiol 141: $457-562$

Kormanik GA, Cameron JN (1981b) Ammonia excretion in animals that breathe water: a review. Mar Biol Lett 2:11-23

Kristensen E (1984) Oxygen and inorganic nitrogen exchange in Nereis virens (Polychaeta) bioturbated sediment-water systems. J coast Res 1:109-116

Livingstone DR, Widdows J, Fieth P (1979) Aspects of nitrogen metabolism of the common mussel Mytilus edulis. Adaptation to abrupt and fluctuating changes in salinity. Mar Biol 53:41-55

Madhyastha MS, Novaczek I, Ablett RF, Johson G, Nijjar MS, Sims DE (1991) A comparative study of uptake and release of glutamic acid and kainic acid by the blue mussel (Mytilus edulis L.). Aquat Toxicol 21:15-28

Maetz $\mathrm{J}(1973) \mathrm{Na}^{+} / \mathrm{NH}_{4}{ }^{+}, \mathrm{Na}^{+} / \mathrm{H}^{+}$exchanges and $\mathrm{NH}_{3}$ movement across the gill of Carassius auratus. J exp Biol 58: $255-275$

Manahan DT, Wright SH, Stephens GG (1983) Simultaneous determination of net uptake of 16 amino acids by marine bivalves. Am J Physiol 244:R832-R838

Mangum CP, Dykens JA, Henry RP, Polites G (1978) The excretion of $\mathrm{NH}_{4}{ }^{+}$and its ouabain sensitivity in aquatic annelids and molluscs. J exp Zool 203:151-157

Morris JG (1991) A biologist's physical chemistry. Edward Arnold, London, p 106-107
Parker M (1988) Sewage sludge disposal in the North Sea. In: Salomons W, Duursma EK, Bayne BL, Förstner U (eds) Pollution of the North Sea. An assessment. Springer-Verlag, Berlin, p 246-256

Prins TC, Smaal AC (1992) Benthic-pelagic coupling: the release of inorganic nutrients by an intertidal bed of Mytılus edulis. In: Barnes M. Gibson RN (eds) Trophic relationship in the marine environments. Proc 24th Mar Biol Symp, Aberdeen University Press, Aberdeen, p 89-103

Rankin JC, Davenport J (1981) Animal osmoregulation (tertiary level biology). Blackie, Glasgow

Regnault M (1987) Nitrogen excretion in marine and freshwater Crustacea. Biol Rev 62:1-24

Ryther JH, Dunstan WM (1971) Nitrogen, phosphorus and eutrophication in the coastal marine environment. Science 171:1008-1013

Sadok S, Uglow RF, Haswell SJ (1995) Determination of ninhydrin positive substances in haemolymph and seawater. Analyst 120:2097-2099

Schaubs BEM, Gieskes WWC (1991) Eutrophication of the North Sea: the relation between Rhine River discharge and chlorophyll a concentration in Dutch coastal water. In: Elliott M, Ducrotoy JP (eds) Estuaries and coasts: spatial and temporal intercomparison. Olsen \& Olsen, Fredensborg, p $85-90$

Taylor BA, Jamieson G, Carefoot TH (1992) Mussel culture in British Columbia: the influence of salmon farms on growth of Mytilus edulis. Aquaculture 108:51-66

Tedengren M, Kautsky N (1987) Comparative stress response to diesel oil and salinity changes of the blue mussel, Mytilus edulis from the Baltic and North Seas. Ophelia 28 (1): $1-9$

Thomas JD, Powles M, Lodge R (1976) The chemical ecology of Biomphalaria giabrata: the effect of ammonia on the growth rate of juvenile snails. Biol Bull mar biol Lab, Woods Hole 151:286-307

Thomas RC (1974) Intracellular pH snail neurones measured with a new $\mathrm{pH}$-sensitive glass micro-electrode. J Physiol 238:159-180

Weber RE, Zwaan A, Bang A (1992) lnteractive effects of ambiant copper and anoxic, temperature and salinity stress on survival and haemolymph and muscle tissue osmotic effectors in Mytilus edulis. J exp mar Biol Ecol 159:135-156

Widdows J, Shick JM (1985) Physiological responses of Mytilus edulis and Cardium edule to aerial exposure. Mar Biol 85:217-232

Wilson RW, Taylor EW (1992) Transbranchial ammonia gradients and acid-base responses to high external ammonia concentration in rainbow trout (Oncorhynchus mykiss) acclimated to different salinities. J exp Biol 166:95-112

Wilson RW, Wright PM, Mungen S, Wood C (1994) Ammonia excretion in freshwater rainbow trout (Oncorhynchus mykiss) and the importance of cell boundary layer acidification: lack of evidence for $\mathrm{Na}^{+} / \mathrm{NH}_{4}{ }^{+}$exchange. $\mathrm{J}$ exp Biol $191: 37-58$

Wright SH, Manahan DT, Stephens GC, Rice MA (1982) Transport of dissolved amino acid by the mussel, Mytilus edulis: demonstration of net uptake from natural seawater. Science 215:1253-1255

Zurburg W, Zwaan A (1981) The role of amino acids in anaerobiosis and osmoregulation in bivalves. J exp Zool 215: $386-397$

Manuscript first received: March 13,1995

Revised version accepted: June 19, 1995 